\title{
Bt corn growing information system in Cagayan Province, Philippines: An analysis for enhanced extension delivery service
}

\author{
Marissa Hernando-Valdez ${ }^{1 *}$ \& Cecilia H. delos Trinos ${ }^{2}$ \\ ${ }^{1}$ Department of Communication Arts, College of Arts and Sciences, Isabela State University, San Fabian, Echague, Isabela, 3309 Philippines \\ ${ }^{2}$ College of Agriculture, Nueva Vizcaya State University, Bayombong, Nueva Vizcaya, 3700 Philippines \\ *Email: marissa.h.valdez@isu.edu.ph
}

\section{ARTICLE HISTORY}

Received: 23 December 2020

Accepted: 08 May 2021

Published online: 01 July 2021

KEYWORDS

Bt corn

Information source

Information system

Communication network

Total information score

\section{ABSTRACT}

The adoption of Bacillus thuringiensis (Bt) corn gene has increased production and agricultural information exchange plays a vital role towards sustained production growth. The study examined the information system by assessing the usefulness of information, frequency of consultations and strength of information exchange in Bt corn production in Cagayan Province, Philippines. Using descriptive correlation design, it was revealed that both technical and economic information from all sources were rated useful. Technical information on seed variety, land preparation, weather forecast, soil management and fertilizer application are frequently utilized while on the economic information only current market prices was frequently used. Frequency of Consultation with personal information sources gained the highest mean value of 5.02 signifying a two to three times exchange of information. Public information sources obtained an average mean of 2.80 which means four or five times contact in a year. This reveals the gap between the corn growers and public information sources. For the mass media sources, both radio (4.56) and television (4.72) are frequently used at two to three times a month. Personal information sources showed strong (224.25 IS) exchange of information between and among the Bt corn growers which comprise their communication network. Total information scores from public and mass media information sources revealed weak exchange of information. The total information score is significantly correlated with membership to organization, years of membership, nature of membership, land ownership and position in the farm. Total information score from friends, radio and newspaper showed significant relationship with income. Thus, information exchange with friends, listening to radio and reading newspaper had a significant influence on the increase of corn growers' income.

\section{Introduction}

Bt maize was first commercialized in the Philippines in 2003, with a rapid rise in its uptake. In 2010, over a quarter million hectares of GM maize were produced by some 270000 Filipino farmers (1). Its adoption was mainly intended to resolve the problem of Asian corn borer, but the major increase and wide-ranging cultivation of Bt corn in the Philippines is due to its alleged economic benefits such as increased yields and increased income for farmers (2). Also, though yield gains from improved weed control have arisen in Argentina, Brazil, Philippines and Vietnam, the use of GM maize has mainly led to lower production costs (3).

Corn production is a major source of livelihood and income for farmers in Region 02. The Philippine Statistics Authority (4) reports that the province of
Cagayan alone accounted for nearly one third or 30.2 per cent of national output. However, maize yields remained low (2 metric tons/ha) and maize imports increased over time (5). Due to the high demand for corn for human consumption, livestock and manufacturing, Cagayan corn growers have also adopted Bt corn not only to answer pest and disease problems, but also to increase productivity.

Access to information on agricultural knowledge is essential in order to boost farmers' capacity to sustain and increase farm productivity (5). Considerations involve the collection of important and timely information and the dissemination of new techniques and technologies. The provision of agricultural information is a key element of the advanced agricultural system, because agricultural information will effectively fill the information gap by helping rural farmers to develop (6). Farmers also use

C Valdez \& delos Trinos (2021). This is an open-access article distributed under the terms of the Creative Commons Attribution License, which permits unrestricted use, distribution and reproduction in any medium, provided the original author and source are credited (https://creativecommons.org/licenses/by/4.0/). 
a variety of contact points to collect information to make sound decision-making. The choice of contact farmers will be focused on the barriers to distribution across social networks. The use of mass media to educate social networks about new technologies would increase demand for information and enable farmers to seek out learning contacts and expand learning (7). Farmer-leading demonstration trials on community-open field days would facilitate appropriate exchange of information among social networks (8).

Corn growers themselves play a crucial role in the transition of suitable agricultural technology and also support extension staff to strengthen the delivery of extension services. However, there are limited data on the agricultural information system for the production of $\mathrm{Bt}$ maize in the region. The results of this study can therefore establish significant frameworks in improving the information system for Bt corn, specifically in terms of information sources, usefulness of information, frequency of use of information, frequency of consultation with information sources and the information system reflected in the total information score. The total information score demonstrates the strength of the exchange of information between corn growers and sources of information that can be used as a basis in developing their network and promoting better extension services. The significant relationship between the respondents' farm characteristics, income and the total information score was also measured in order to evaluate the factors that lead to the improvement of their income. This study can serve as a means of enhancing the provision of information extension services for the production of Bt corn, thereby enhancing the information communication network and the productivity in agriculture.

\section{Materials and Methods}

This is a descriptive correlational study. The study employed snowball or chain referral sampling technique to generate the research informants. The Municipal Agriculturist Officer (MAO) of the municipalities generated initial respondents. A total of 293 corn growers from the six towns: Abulog, Amulong, Alcala Gattaran, Peñablanca and Piat Cagayan who owns at least 0.50 hectares of Bt corn were selected as respondents in the study. They were interviewed and asked to name their closest friends who were the source of corn production information and who would make up their personal network.

A pre-tested standardized questionnaire was used to collect quantitative data or variable information: sources of information, perceived degree of usefulness of information, frequency of use of information, frequency of consultation of sources.

For ethical purposes, prior to the conduct of the study, adequate planning was undertaken with the local government offices. The respondents were told in a consent form that their involvement was completely voluntary and that details would be dealt with strict confidentiality.

\section{Data Analysis}

Frequency count and percentage was used to present the socio-demographic profile of the respondents; weighted means was used to determine the perceived degree of usefulness of the information sources and Pearson Moment of Correlation was used to establish relationship between the total information score and socio-demographic profile of the respondents.

The Bt Corn growers' communication network was analyzed using the frequency of contact with information sources, perceived degree of usefulness of information provided and total information scores from the sources of information. Frequency of contact was evaluated using the scale and weights that were given according to the frequency of contact for each variable as follows:

\begin{tabular}{ccl}
\hline Scale & Weights & Frequency of Contact/s \\
\hline 0 & 0 & no contact \\
\hline 1 & 1 & once a year \\
\hline 2 & 2 & two or three times a year \\
\hline 4 & 4 & four or five times a year \\
\hline 5 & 12 & once a month \\
\hline 6 & 30 & two or three times a month \\
\hline 7 & 52 & once a week \\
\hline 8 & 130 & two or three times a week and \\
\hline \multicolumn{5}{c}{ The } & perceived & degree of usefulness \\
information produced was weighted as follows: \\
\hline Scale & \multicolumn{3}{c}{ Weights } & Degree of Usefulness \\
\hline \multicolumn{5}{c}{0} & 0 & not useful at all \\
\hline 0.25 & $0.01-0.25$ & little useful \\
\hline 0.50 & $0.26-0.50$ & moderately useful \\
\hline 0.75 & $0.51-75.00$ & useful \\
\hline 1.0 & $0.75-1.00$ & very useful
\end{tabular}

The information system was evaluated using the total information score (TIS). The formula is adopted from Demiryurek (9):

$$
\text { TIS }=\text { FC } x \text { IU }
$$

where: $\mathrm{FC}=$ the number of times farmers come in contact with information sources;

$\mathrm{IU}=$ the usefulness of information

\section{Results and Discussion}

\section{Socio-demographic Characteristics of the Respondents}

Supplementary Table 1a describes the socioeconomic characteristics of the Bt corn grower respondents. The majority of respondents are male (76.45\%), the majority (32.08\%) are between 41 and 50 years of age and the average age of respondents was 49.01 years of age. This confirms that the aging phenomenon of farmers is true of smallholder farmers in Asia (10). Most Filipinos regard education as a top priority for their children, as reflected in the data. Educational level has shown that most of them are high school graduates (31.06\%), which indicates that corn growers are highly literate. The majority of workers in the Philippines have completed at least high school; however, better trained workers prefer to work outside agriculture (11).

A large majority (90.10\%) of them are not members to organizations. Corn growers who have 
organizational affiliation (82.76\%) has been members between $0-10$ years with a mean of 5.59 years. Many $(89.66 \%)$ of them are members while few $(10.3 \%)$ are officers. This implies that most of the corn growers do not participate to corn related organization; thus, most of them would depend on information available to them. According to another study, (12) for every one-year increase in membership of a farmer group, there is a 0.071 increase in the probability that a farmer will adopt Bt corn. A study (13) suggests that farmers may set up alliances or organizations to help provide the inputs they need at lower prices and to assist them in marketing their products to identified markets. Market information such as the prevailing prices offered by traders can also be provided by this organization. They can also capitalize on obtaining effective and productive machinery along with their fellow farmers for those farmers who do not have the ability to access equipment.

Supplementary Table $1 \mathrm{~b}$ displays the farm characteristics of the Bt corn growers. A little more than half (52.90\%) have been growing corn for around 21 years. Which means they have dedicated their lives in growing corn and a good indication that it is a good source of income.

Majority $(64.85 \%)$ of them are landowners. In terms of farm area planted with corn, most (41.13\%) of them cultivate $1.00-1.99$ ha. and on average owns 1.52 ha. It was mentioned in a study (12) that it is possible that farmers who own their land are likely to adopt Bt corn six times over.

While yield may only be a partial gauge of performance, it reflects the available production technology across farms. It was revealed that the average farm yield is 82.53 cavans per ha or 4.13 tons. More than half (54.89\%) had farm yield of 51100 cavans per ha. It was also shown that Php $37,302.14$ is the average net income per ha. A study revealed (14) as their produce had better quality and purity, Bt corn farmers were also able to receive premium prices on the market.

\section{Agricultural Information System}

\section{Sources of Information.}

The major sources of information used in this analysis are personal information sources: family members, relatives, friends and neighbours; public information sources are sources outside the community: agricultural technicians, researchers, experts, agro-chemical sales representatives; and the mass media sources are print materials, e-media and broadcast media. The information is categorized into technical and economic information.

Usefulness of the information (Supplementary Table 2) the study describes the condition in which farmers consider the information produced from the three sources of having beneficial impact in corn production.

The technical information from the three sources collectively obtained a mean score of 0.77 , 0.73 and 0.73 which indicates that the technical skills in corn farming are useful. From the information, seed variety, land preparation, weather forecast and harvesting fertilizer application were considered very useful. Other information were rated useful except for storage methods and techniques which was considered moderately useful. Another study (15) claimed that the lack of knowledge of farmers on market requirements and post-harvest facilities for producing high-quality maize, the trader/processor/integrator repeated some of the farmers' activities, especially in shelling, drying, storage and marketing.

The informants claimed that manual harvesting is still being practiced due to the lack of machinery. In addition, they reported that corn produced is not stored for a long time because it is sold immediately after harvest, or lending institutions or individuals directly haul their produce to cover the loans from farm inputs. According to a study (9) with high production costs, they are forced to borrow money from informal lenders who charge them high interest rates, or traders who allow them to sell their produce with a low paddy price right after harvest.

The weighted mean of economic information generated from the three sources is $0.70,0.72$ and 0.71 or described as useful. Three items, current market prices future market prices and credit sources have been classified as very useful. The rest of the information were rated useful, indicating that they consider economic information practically important. A study (16) indicated that the economic gains is the rise in income by the use of Bt corn as feed rations, family members as labourers and children's education is derived from their income in Bt corn feeds.

\section{Frequency of utilization of information}

Supplementary Table 3 indicates the frequency of utilization of information. The weighted mean scores obtained under the technical information were 0.68 , 0.72 and 0.070 respectively rated as frequently used. Information on seed variety, land preparation, weather forecast, soil management and fertilizer application are frequently utilized. The rest of the information are moderately used excluding storage methods and techniques that have been used slightly and moderately. In terms of economic information, only current market prices were frequently used. The result suggests that corn growers relatively utilize information on the techniques on the production component in corn growing.

Many of them rarely practice storage methods and techniques since they directly sell their produce. Additionally, information on stock/record keeping, cooperative association, risk management in agriculture were seldom utilized which validates the findings that most of respondents are not affiliated to organization.

Therefore, equipping farmers with entrepreneurial skills and providing them financial resources through collaboration between the government with private investors and socio-civic organizations to revive interest in agriculture by positioning it as an enticing and viable alternative is recommended (17). 


\section{Frequency of Consultation with Information Sources}

Supplementary Table 4 presents the frequency of consultations with information sources. The general mean obtained from personal sources is 5.02 or consultation is carried out two or three times a month. It was also found out that, once a week, corn growers talk with family members about corn farming with a mean of 5.42, which means that the family is the leading source of knowledge for corn growing. Trust among farmers may be one reason why word-of-mouth, testimonials, advice and other types of knowledge from fellow farmers play a key role in the actions taken by farmers and this level of confidence may be lacking in down-to-earth communication, such as extension services (18).

Public information sources are accessed only four to five times a year (2.80). However, it is worth noting that most corn growers will request knowledge from the Municipal Agricultural Technician on the highest average of 3.53. It shows that the majority of corn growers still trust the people of the Department of Agriculture to collect information from the public sources of information. The result justifies the claim (19) that access to extension services will make a major contribution to the evaluation of the utility and use of recommended information and technology by farmers, given that most farmers will meet extension workers only once a year.

The corn growers often use radio (5.31) and TV (4.72) as sources of information described as two or three times a month when it comes to mass media sources. Another study (20) showed that electronic communication (radio, TV) can play a vital role in the timely distribution of critical information to farmers in urgent and emergency situations. Farmers are informed about pests and pest control, flooding and the changing weather promptly and easily.

Results show that other channels such as printed materials and cellphone were used Four or Five Times a Year while the farm journal/magazine and the internet two or three times a year. This means corn growers consult broadcast mediums regularly for information while occasionally relying on print materials and modern technologies such as cellular phone and the internet. Lack of connectivity, such as accessibility and easy access to farmers ' markets and mobile networks, are also some of the key reasons why farmers use mobile phones less to gain updated market information on their produce (21).

\section{Total Information Score}

Suggest the strength of contact information between the Bt corn growers and their information sources classified into weak (IS>74), moderate $(75<$ IS $<149)$ and strong ( $>150)$.

Based on the result as shown in Supplementary Table 5, personal information sources collected an average of 224.25 IS with a range of IS $>150$. The family members earned the highest mean score (240 IS), followed by friends (230 IS), relatives (229 IS and co-corn growers (198). This means that there is a clear system of knowledge exchange between the subsystem of personal information sources and the distribution of information within and between corn growers. In addition, it can be concluded that there is an exchange of information and experience on corn farming among corn farmers in their own network. Farmers also rely on their casual social contacts as the most reliable and accurate source of knowledge on the suitability, feasibility, profitability and use of new technologies (22). According to a study (23), when making decisions on who to seek advice or with whom to exchange inputs, farmers will always reach out to peers who have shown clear signs of good farming practices.

The Public information sources were driven by professional staff of various institutions and they serve as information sources from outside the communities. Ideally, they are expected to provide the farmers with scientific and technical extension support services. As a motivator, trainer, dynamist, communicator and counselor to farmers, the key role of agricultural extension is to introduce sustainable agricultural growth programmes that are unique to the location and can increase farmers 'income (24). Moreover, a study concluded (25) that local extension workers who serve as the direct source of agricultural information for farmers should be given guidance on Bt corn varieties so that they can guide farmers to make informed decisions; and local extension workers should play an active role in monitoring the adoption of Bt corn within the locality to provide policy decision-making data.

However, the results reveal that the public information sources obtained a mean of 70.80 IS which indicates low contact with the farmers. Thus, farmers rarely get information from agricultural technicians, university extension workers, researchers and experts. The informants mentioned that insufficient funds, personnel and mobility as factors. It is suggested to conduct farmer to farmer extension and consider engaging some progressive farmers as extension workers who may undergo field-based hands-on training to strengthen their technical knowledge (18) According to a study (26) via facilitation, extension staff will greatly assist farmers in handling position changes. Therefore, recognizing and encouraging role changes is necessary for on-farm experiments to be maintained.

Mass media sources gained a low information score (40.33 IS). Mass media sources were viewed as least reliable, and their information was used in the awareness-raising process of adopting agricultural technologies (27). Among the sources, TV (127 IS) and radio (110 IS) obtained scores that fall within moderate information score. The result suggests that farmers adequately produce information from watching TV and listening to radio since these are the commonly used and available medium to transfer agricultural information to a large number of people. Radio and television have been recognized as the most powerful means of disseminating scientific information to the public (28). The rest of the mass media channels obtained low information scores that may be considered least consulted due to the limited 
diffusion of information to the farmers. Likewise, internet access is limited for them to search for online information.

\section{Relationship between Variables}

Supplementary Table 6 shows the correlation between farm characteristics and farmers' total information score. It was revealed that membership to organization, years of membership and nature of membership resulted to have a relationship with total information score. The members who have been with the organization for a long time especially the officers have better access to information. Likewise, only land ownership and position in the farm are significantly correlated with total information score. Farmers who do not own and just renting or shared tilling the farm had higher information score. This means that farm owners had meager access to information communication. This findings is related to the study (29) which claims that renters often use a wider range of information sources and contact networks than owners. Renters who practice conservation are more likely to be early adopters of other technologies because they are highly networked and not dependent on a single type of knowledge.

The relationship between the income of the respondents and the total knowledge score is shown in Supplementary Table 7. Friends, radio and newspaper were found to have a substantial contribution to the increase in income among the dependent variables considered. A study (30) noted that interpersonal networks are important to farmers and influence farmer learning and decision-making, and farmers often see each other as their key source of knowledge.

This is likely to indicate that increased interaction between the corn farmers and their friends, listening to the radio and reading the newspaper, has had an impact on their income growth. Constant consultation and use of these sources can also increase the productivity of farmers. Previous study (31) found that the related coverage of weather forecasts and plant protection strategies was generated by newspapers and radio broadcasts to address key factors affecting agricultural productivity. Minor coverage is also given for other primary agricultural variables, such as technology and knowledge of crop varieties.

\section{Conclusion}

It was revealed in the study that there is a strong personal information network among the Bt corn growers. Organizing them together with the conduct of model farms visits and farmers' field day will strengthen their connections and network. Given the gap between the corn growers and public information sources, regular conduct of two-way exchange of information process between the sources of information either experts, extension workers-led or farmer-led method will facilitate efficient generation and application of relevant technologies in Bt corn growing. Linkage between the researchers, experts, extension worker and corn grower performers will intensify information delivery systems and bring relevant and timely information resource needed. TV and radio were often consulted mass media sources, thus, regular TV agripreneurship and sustainable, timely and relevant school-on-the-air programming are recommended. Bt corn growers may consider further studies, attend trainings and skills development to capacitate them on business knowledge to optimize agricultural returns. Although new technologies remain weak sources, development of ICTs to facilitate the dissemination of information are encouraged to adapt to the demand of the changing times. This way, easier access and information exchange will expand communication network thereby improving the delivery of extension services.

\section{Acknowledgements}

The authors are grateful to the Commission on Higher Education (CHED) Discovery-Applied Research and Extension for Trans/Inter-disciplinary Opportunities (DARETO) of the Republic of the Philippines for funding the study.

\section{Authors' contributions}

In this article, the authors contributed equally.

\section{Conflict of interests}

The authors hereby state that no conflict of interest is involved.

\section{Supplementary files}

Table 1a. Socio-demographic characteristics of Bt corn grower respondents

Table 1b. Farm characteristics of Bt corn growers

Table 2. Perceived degree of usefulness of information from personal, public and mass media sources

Table 3. Frequency of utilization of information from personal, public and mass media sources

Table 4. Frequency of consultation with information sources

Table 5. Information system and communication network in corn production

Table 6. Correlation between fam characteristics and total information score of the respondents

Table 7. Correlation between income and total information score of the respondents

\section{References}

1. James C. Global Status of Commercialized Biotech/GM Crops: [Internet] 2010. [Cited 2020 Aug 27] ISAAA Brief No. 42. ISAAA Ithaca, NY.

2. Afidchaio M, Musters CJM, Wossink A, Balderama O, de Snoo G. Analysing the farm level economic impact of GM corn in the Philippines. NJAS - Wageningen Journal of Life Sciences. 2014;70 71:113-21. https://doi.org/10.1016/j.njas.2014.05.008 
3. Brookes G, Barfoot P. Farm income and production impacts of using GM crop technology 1996-2016. GM Crops and Food. 2018;9(2):59-89. https://doi.org/10.1080/21645698.2018.1464866

4. Q2 Palay Production down by more than one percent. [Internet] [cited 2020 Aug 15] Available from: http://rsso02.psa.gov.ph/article/q2-palay-production-down-moreone-percent-0

5. Mutuc ME, Rejesus RM, Pan S, Yorobe Jr JM. Impact assessment of Bt corn adoption in the Philippines. Journal of Agricultural and Applied $\quad$ Economics. 2012;44:117-35. https://core.ac.uk/download/pdf/6653009.pdf

6. Pratiwi A, Suzuki A. Effects of farmers' social networks on knowledge acquisition: lessons from agricultural training in rural Indonesia. Economic Structures. 2017:6, Article no.8. https://doi.org/10.1186/s40008-017-0069-8

7. Yaseen M, Xu S, Yu W, Hassan S. Farmers' access to agricultural information sources: Evidences from rural Pakistan. Journal of Agricultural Chemistry and Environment. 2016;5:12-19. https://doi.org/10.4236/jacen.2016.51B003

8. Fuglie K, Gautam M, Goyal A, Maloney WF. Harvesting Prosperity Technology and Productivity Growth in Agriculture. Washington, DC: World Bank. 2020. [Cited 2020 Oct 10] https://doi.org/10.1596/978-1-4648-1393-1

9. Demiryurek K, Erdem H, Ceyhan V, Atasever S, Uysal O. Agricultural information systems and communication networks: the case of dairy farmers in Samsun province of Turkey Information Research. 2008;13(2):343. [cited 2020 Jan 7]. http://InformationR.net/ir/13-2/paper343.html

10. Palis F. Aging Filipino rice farmers and their aspirations for their children. Philippine Journal of Science. 2020;149(2):351-61. [cited 2020 Aug 20]. http://philjournalsci.dost.gov.ph/images/pdf/pjs_pdf/ vol149no2/aging_filipino_rice_farmers_.pdf

11. Briones R. Characterization of Agricultural Workers in the Philippines. 2017 [cited 2020 Sept 22] Available from https://pidswebs.pids.gov.ph/CDN/PUBLICATIONS/pidsdps1731.pdf

12. Naval R. Dolojan F. Determinants of Bt corn (Zea mays L.) Adoption in Cagayan Valley, Philippines. Journal of Critical Reviews. Journal of Critical Reviews. 2020;7(11):9-13. http://www.jcreview.com/fulltext/03_v1.pdf?1620920601

13. Signabon LFB, Madamba JAB, Mojica LE, Manipol NEP, Miranda HD. Decision determinants of indigenous corn farmers in Northern Philippines. Asia-Pacific Journal of Business. 2017;8, (1,):45-65.

https://www.koreascience.or.kr/article/JAKO201731063138917.pdf

14. APAARI. GM Maize in the Philippines - A Success Story. AsiaPacific Association of Agricultural Research Institutions, Bangkok, Thailand. [Internet] 2019. [cited 2020 Oct 20] Available from: http://apaari.org/web/wpcontent/uploads/downloads/2019/GM \%20Maize\%20in\%20Phillippines-Success\%20Story_28-3-2019.pdf

15. Calica G, Eleria N. Agreements and Relationships of Market Actors for Mindanao Yellow Corn. International Journal of Scientific Research and Management. 2018;6(6). https://doi.org/10.18535/ijsrm/v6i6.sh02

16. Bernardo JM. Assessment of the social and economic gains and needs in adopting Bt (Bacillus thuringiensis) corn feed rations in San Jacinto, Pangasinan, Philippines. [Internet] 2017. [cited 2020 Oct 15] Available from: https://agris.fao.org/agris-search/search.do? recordID=PH2019000233

17. Santiago A, Roxas F. Reviving farming interest in the Philippines through agricultural entrepreneurship education. Journal of Agriculture, Food Systems and Community Development. 2015;5(4):15-27. http://dx.doi.org/10.5304/jafscd.2015.054.016

18. Ramirez A. The Influence of Social Networks on Agricultura Technology Adoption. Procedia - Social and Behavioral Sciences. 2013;79:101-16. https://doi.org/10.1016/j.sbspro.2013.05.059

19. Baloch M, Thapa G. The effect of agricultural extension services: Date farmers' case in Balochistan, Pakistan. Journal of the Saudi Society of Agricultural Sciences. 2018;17:282-89. http://dx.doi.org/10.1016/j.jssas.2016.05.007

20. Aldosari F, Al Shunaifi MS, Ullah MA, Muddassir M, Noor MA Farmers' perceptions regarding the use of Information and
Communication Technology (ICT) in Khyber Pakhtunkhwa, Northern Pakistan. I Saudi Soc Agri Sci. 2019;18(2):211-17. https://doi.org/10.1016/j.jssas.2017.05.004

21. Chhachhar AR, Jianbin Jin CC. Mobile phone impact on agriculture and price information among farmers. Indian Journa of Science and Technology. 2016;9:39:1-11. https://dx.doi.org/10.17485/ijst/2016/v9i39/98432

22. Ben Yishay A, Mobarak M. Communicating with Farmers through Social Networks. Economic Growth Center Discussion Paper [Internet] 2013. [cited 2020 Sept 26]; No.121 Available from http://papers.ssrn.com/sol3/papers.cfm?abstract_id=2315229

23. Wood BA, HT Blair, DI Gray, PD Kemp, PR Kenyon, ST Morris, AM Sewell. Agricultural science in the wild: a social network analysis of farmer knowledge exchange. PLoS ONE. 2014;9(8):e105203. http://dx.doi.org/10.1371/journal. pone.0105203

24. Eastwood C, Klerkx L, Nettle. R. Dynamics and distribution of public and private research and extension roles for technological innovation and diffusion: Case studies of the implementation and adaptation of precision farming technologies. Journal of Rural Studies.

https://doi.org/10.1016/j.jrurstud.2016.11.008

25. dela Torre Baconguis R, Peñalba LM, Elazegui DD, Dumayas EE. The role of agricultural public extension in a private-led technological innovation. In: Gurtoo A, Williams C. (editors) Developing country perspectives on public service delivery Springer, New Delhi. [Internet] 2015. [cited 2020 Sept 18] https://doi.org/10.1007/978-81-322-2160-9_14

26. Hauser M, Lindtner M, Prehsler S, Probst L. Farmer participatory research: why extension workers should understand and facilitate farmers' role transitions. J Rural Stud. 2016;47:52-61. https://doi.org/10.1016/j.jrurstud.2016.07.007

27. Meena, B. Communication Sources Credibility and Utilization Pattern among Farmers. Small. 2010;46:23. http://rseeudaipur.org/ wp-content/uploads/2013/02/10.pdf

28. Nazari M, Hassan M. The Role of Television in the Enhancement of Farmers' Agricultural Knowledge. African Journal of Agricultural Research. 2011;6(4):931-36. https://doi.org/10.5897/AJAR10.1154

29. Varble S, Secchi S, Druschke CG. An Examination of Growing Trends in Land Tenure and Conservation Practice Adoption: Results from a Farmer Survey in Iowa. Environmental Management. 2016;57:318-30. https://doi.org/10.1007/s00267-015 0619-5

30. Skaalsveen K, Ingram J, Urquhart J. The role of farmers' socia networks in the implementation of no-till farming practices. 2020;181:102824. https://doi.org/10.1016/j.agsy.2020.102824

31. Khan N, Siddiqui BN, Khan N, Ullah N, Ismail S, Ali S, Hussain S Abbas K, Javed HH, Ahmad Z. Impact of newspaper and radio in promoting agricultural information among farmers. A case study of Pakistan. Int J Adv Res Biol Sci. 2020;7(4):192-198. http://dx.doi.org/10.22192/ijarbs.2020.07.04.024

\section{Additional information}

Peer review information: Plant Science Today thanks Sectional Editor and the other anonymous reviewers for their contribution to the peer review of this work.

Reprints and permissions information is available at https://horizonepublishing.com/journals/index.php/PST/open_access_policy

Publisher's Note: Horizon e-Publishing Group remains neutral with regard to jurisdictional claims in published maps and institutional affiliations.

To cite this article: Valdez $\mathrm{M} \mathrm{H}, \mathrm{C} \mathrm{H}$ delos Trinos. Bt corn growing information system in Cagayan Province, Philippines: An analysis for enhanced extension delivery service. Plant Science Today. 2021;8(3):445 450. https://doi.org/10.14719/pst.2021.8.3.1062

Plant Science Today, published by Horizon e-Publishing Group, is covered by Scopus, Web of Science, BIOSIS Previews, Clarivate Analytics, etc. See https://horizonepublishing.com/journals/index.php/PST/indexing_abstracting 